\title{
PENGARUH KARAKTERISTIK PERUSAHAAN TERHADAP PENGUNGKAPAN CORPORATE SOCIAL RESPONSIBILITY (CSR) PADA LAPORAN TAHUNAN DI INDONESIA
}

\author{
Dahniyar Daud *) \\ niardaudismail@gmail.com
}

\begin{abstract}
ABSTRAK
Penelitian ini bertujuan untuk mengetahui apakah laporan tahunan perusahaan memiliki hubungan serta pengaruh terhadap Laporan keuangan Corporate Social Responsibility (CSR) dan mengetahui karakteristik ukuran dewan komisaris, tipe industri, ukuran perusahaan, profitabilitas, kepemilikan saham asing, dan kepemilikan saham publik. Penelitian ini menggunakan pengujian analisis linier berganda. pada sektor manufaktur yang tercatat di Bursa Efek Indonesia (BEI) tahun 2011-2012, diperoleh hasil bahwa ukuran dewan komisaris, tipe industri, profitabilitas, kepemilikan saham publik berpengaruh positif terhadap corporate social responsibility (CSR) dan ukuran perusahaan dan kepemilikan saham asing berpengaruh negatif terhadap corporate social responsibility $(C S R)$ perusahaan di Indonesia.
\end{abstract}

\section{Pendahuluan}

Kondisi dunia yang tidak menentu seperti terjadinya globalwarming, kemiskinan yang semakin meningkat, memburuknya kesehatanmasyarakat serta tuntutan sosial kepada perusahaan, memicuperusahaan dalam mengungkapkan tanggungjawab sosial (sosialresponsibility) perusahaan pada seluruh stakeholder yang terdiri darikaryawan, investor, pemerintah, masyarakat, konsumen dan pemasok,serta kelangsungan generasi penerus, karena itu muncul pula kesadaranuntuk mengurangi dampak negatif ini dengan menggunakan pendekatantanggungjawab sosial dan lingkungan atau dikenal dengan sebutanCorporate Social Responsibility (CSR), perusahaan tidak hanyamendapatkan keuntungan ekonomi, keuntungan sosial, tetapikeberlangsungan usaha tersebut dapat berlangsung dengan baik dansecara tidak langsung akan mencegah konflik yang merugikan danmeningkatkan kualitas masyarakat sekitar (termasuk karyawan, pemasok,dan pelanggan) serta lingkungan yang menjadi pemangku kepentinganatau stakeholder.

Seluruh perusahaan di Indonesian semakin dituntut untuk memberikan informasi yang transparan atas aktivitas sosialnya, sehingga pengungkapan terhadap Corporate sicial responsibility (CSR) diperlukan peran dari akuntansi pertanggungjawaban sosial (Angraini, 2006). Akuntansi pertanggungjawaban sosial berperan menjalankan fungsinya sebagai bahasa bisnis yang mengakomodasi masalah-masalah sosial yang dihadapi oleh perusahaan, sehingga pos-pos biaya sosial yang dikeluarkan kepada masyarakat dapat menunjang operasional dan pencapaian tujuan jangka panjang perusahaan.Dalam mengakomodasi masalah sosial yang dihadapi oleh perusahaan, diperlukannya 
informasi yang lengkap mengenai dampak lingkungan sosial yang ditimbulkan oleh aktivitas entitas bisnis sehingga dapat menjadi bahan pertimbangan bagi perusahaan untuk mendeteksi secara langsung stabilitas lingkungan sosial dan hubungannya dengan kelangsungan hidup perusahaan.

Permasalahan-permasalahan sosial yang dihadapi oleh perusahaan di Indonesia juga terjadi karena lemahnya penegakan peraturan tentang tanggung jawab sosial perusahaan, misalnya aturan ketenagakerjaan, pencemaran lingkungan, perimbangan bagi hasil suatu industri dalam era otonomi daerah. Selain itu, dalam Pernyataan Standar Akuntansi Keuangan (PSAK) No. 1 (revisi 2009,7:12) masih bersifat sekarela dalam mengungkapkan CSR kepada publik melalui laporan tahunan perusahaan.

Penelitian terdahulu oleh Sembiring (2005), (Eka Nanda Putra, 2011:23) mengenai karakteristik perusahaan dan pengungkapan tnggung jawab sosial: studi empiris pada perusahaan yang tercatat di Bursa Efek Jakarta, faktor-faktor yang diindikasikan mempengaruhi pengungkapan CSR antara lain: ukuran perusahaan, profitabilitas, tipe industri, ukuran dewan komisaris, dan leverage. Namun, berbeda dengan peneliti terdahulu penelitian ini ingin mencoba untuk mengadopsi faktor-faktor tersebut sebagai varibel penelitian, antara lain: faktor ukuran dewan komisaris, tipe industri, ukuran perusahaan, profitabilitas, dan kepemilikan saham publik. Berdasarkan latar belakang di atas maka penelitian ini dimaksudkan untuk menganalisis Pengaruh Karakteristik Perusahaan Terhadap Pengungkapan Corporate Social Responsibility (CSR). Skripsi ini membahas penelitian secara teoritis, sehingga diharapkan dapat memberikan kontribusi positif dari perkembangan pengungkapan $C S R$ pada laporan tahunan perusahaan berbagai sektor bisnis di Indonesia.

\section{Rumusan Masalah}

Berdasarkan latar belakang di atas, maka rumusan masalah yang disajikan dalam penelitian ini adalah :

1. Apakah ukuran dewan komisaris memiliki pengaruh terhadap pengungkapan CSR dalam laporan tahunan perusahaan di Indonesia?

2. Apakah tipe industri memiliki pengaruh terhadap pengungkapan CSR dalam laporan tahunan perusahaan di Indonesia?

3. Apakah ukuran perusahaan memiliki pengaruh terhadap pengungkapan CSR dalam laporan tahunan perusahaan di Indonesia?

4. Apakah profitabilitas memiliki pengaruh terhadap pengungkapan CSR dalam laporan tahunan di Indonesia?

5. Apakah kepemilikan saham publik memiliki pengaruh terhadap pengungkapan CSR dalam laporan tahunan di Indonesia?

\section{Tujuan Penelitian}

Adapun tujuan penelitian ini yaitu :

1. Mengetahui pengaruh ukuran dewan komisaris terhadap pengungkapan $C S R$ dalam laporan tahunan perusahaan di Indonesia. 
2. Mengetahui pengaruh tipe industri terhadap pengungkapan CSR dalam laporan tahunan di Indonesia.

3. Mengetahui pengaruh ukuran perusahaan terhadap pengungkapan CSR dalam laporan tahunan di Indonesia.

4. Mengetahui pengaruh profitabilitas terhadap pengungkapan CSR dalam laporan tahunan di Indonesia.

5. Mengetahui pengaruh kepemilikan saham publik terhadap pengungkapan CSR dalam laporan tahunan di Indonesia.

\section{Tinjauan Pustaka}

\section{Pengertian Corporate Social Responsibility (CSR)}

Defenisi CSR menurut Suhandari (2007:1) merupakan komitmen perusahaan atau dunia bisnis untuk berkontribusi dalam pengembangan ekonomi yang berkelanjutan dengan memperhatikan tanggungjawab sosial perusahaan dan menitikberatkan pada keseimbangan antara perhatian terhadap aspek ekonomi, sosial, dan lingkungan.

Menurut CSR Asia seperti dikutip Darwin (2008) pada penelitian Ahmad Nurkhin (2009:14) CSR merupakan mekanisme bagi suatu organisasi untuk suka rela mengintegrasikan perhatian terhadap lingkungan dan sosial ke dalam operasinya dan interaksinya dengan stakeholders, yang melebihi tanggung jawab organisasi di bidang hukum. Pertanggungjawaban sosial perusahaan diungkapkan di dalam laporan yang disebut Sustainability Reporting. Sustainability Reporting adalah palaporan mengenai kebijakan ekonomi, lingkungan sosial, pengaruh, kinerja organisasi dan produknya dalam konteks pembangunan berkelanjutan (sustainable development) Astrotamma (2009) dalam penelitian yang pernah dilakukan oleh Eka Nanda Putra (2011:39).

\section{Karakteristik Perusahaan Terhadap Pengungkapan CSR}

Dalam penelitian ini karakteristik perusahaan yang mempengaruhi pengungkapan $C S R$ dalam laporan tahunan perusahaan yaitu, ukuran dewan komisaris, tipe industri, ukuran perusahaan, profitabilitas, dan kepemilikan saham publik.

\section{Ukuran Dewan Komisaris}

Dewan komisaris merupakan wakil shareholder didalam suatu entitas yang berbadan hukum perseroan terbatas. Selain sebagai wakil shareholder, dewan komisaris memiliki tugas untuk mengawasi, memberikan pengarahan pada pengelolah perusahaan yang dilaksanakan oleh manajemen (direksi), dan bertanggung jawab untuk menentukan apakah manajemen memenuhi tanggung jawab mereka dalam mengembangkan, serta menyelenggarakan pengendalian intern perusahaan Mulyadi, (1998:174). Dengan wewenang yang dimilikinya, dewan komisaris dapat memberikan pengaruh yang cukup kuat untuk menekan manajemen untuk mengungkapkan tanggung jawab sosial perusahaan.

Banyaknya jumlah dewan komisaris didalam entitas, maka akan menentukan pengaruhnya terhadap pengungkapan tanggung jawab sosial perusahaan. Beasley dan Salterio (2001) pada penelitian Edy Suranta dan Pranata 
Puspa Midiastuty, (2005:2) menyatakan bahwa semakin besar jumlah anggota dewan komisaris, maka akan semakin mudah mengendalikan Chief Executive Officer (CEO) dan monitoring yang dilakukan semakin efektif. Dengan demikian, semakin besar jumlah dewan komisaris maka akan semakin mudah menekan $C E O$ untuk mengungkapkan $C S R$.

\section{Tipe Industri}

Tipe industri adalah sejenis entitas bisnis berdasarkan sektor usaha yang digerakkannya. Tipe industri diklasifikasikan menjadi dua jenis, yaitu tipe industri highprofile dan tipe industri low-profile. Robert (1992) pada penelitian Angraini (2006:6) menjelaskan bahwa tipe industri high-profile merupakan perusahaan yang mempunyai tingkat sensivitas yang tinggi terhadap lingkungan, tingkat risiko politik yang tinggi atau tingkat kompetisi yang ketat. Keadaan tersebut membuat perusahaan menjadi lebih mendapatkan sorotan oleh masyarakat luas mengenai aktivitas usaha yang digeraknya. Sedangkan, tipe industri low-profile merupakan perusahaan yang mempunyai tingkat consumer visibility, tingkat risiko politik, dan tingkat kompetisi yang rendah, sehingga tidak terlalu mendapat sorotan dari masyarakat luas mengenai aktivitas yang digerakannya, meskipun dalam melakukan aktivitasnya tersebut perusahaan melakukan kesalahan atau kegagalan pada proses maupun hasil produksinya.

\section{Ukuran Perusahaan}

Ukuran perusahaan (corporate size) merupakan suatu skala yang berfungsi untuk mengklasifikasikan besar kecilnya suatu entitas bisnis. Skala ukuran perusahaan dapat mempengaruhi luas pengungkapan informasi dalam laporan keuangan mereka. Secara umum, perusahaan besar akan mengungkapkan informasi sosial atau tanggung jawab sosial lebih banyak dari pada perusahaan kecil. Hal ini dapat dijelaskan secara teoritis bahwa perusahaan besar merupakan entitas bisnis yang tidak lepas dari risiko tekanan politis yang lebih besar dibandingkan perusahaan kecil. Tekanan politis ialah tekanan untuk entitas bisnis yang banyak disoroti oleh masyarakat luas agarlebih mengungkapkan tanggung jawab sosial atas aktivitas usahanya terhadap lingkungan sekitarnya. Hasibuan (2001) pada penelitian Marzully Nur dan Denies Priantinah (2012:25) menjelaskan bahwa dengan adanya pengungkapan aktivitas sosial yang lebih besar merupakan pengurangan biaya politis bagi perusahaan, sehingga perusahaan dalam waktu jangka panjang akan terhindar dari biaya yang sangat besar akibat tuntutan masyarakat.

\section{Profitabilitas}

Profitabilitas merupakan faktor yang membuat manajemen menjadi bebas dan fleksibel untuk mengungkapkan CSR kepada pemegang saham (Heinze, 1976; Gray et al., 1995; pada penelitian Angraini, 2006:10), sehingga dapat dijelaskan bahwa profitabilitas merupakan kemampuan entitas untuk menghasilkan laba demi meningkatkan nilai pemegang saham. Oleh karena itu, semakin tinggi tingkat profitabilitas perusahaan maka semakin besar pengungkapan informasi sosialnya.

Penelitian yang dilakukan oleh Hackston dan Milne (1996) yang pernah ditulis dalam Marzully Nur dan Denies Priantinah (2012:25) sejalan dengan riset penelitian empiris yang dilakukan oleh Angraini (2006) yang menyatakan bahwa tidak ditemukan hubungan antara profitabilitas dengan pengungkapan informasi sosial atau tanggungjawab sosial perusahaan. 


\section{Kepemilikan Saham Publik (Public Shareholding)}

Kepemilikan saham publik adalah proporsi kepemilikan saham yang dimiliki oleh publik/masyarakat terhadap saham perusahaan di indonesia. Publik sendiri adalah individu atau institusi yang memiliki kepemilikan saham di bawah 5\% yang berada diluar manajemen dan tidak memilik hubungan istimewa dengan perusahaan Suchman, (1995) pada penelitian Desie Rakhmawati, (2011:21). Sementara perusahaan perseroan (PT) yang memiliki saham perusahaan yang bersangkutan, tidak dimasukkan dalam kategori publik, pertimbangan ini dilakukan karena dapat menjadikan luas pengungkapan laporan keuangan tidak banyak berpengaruh terhadap keputusan manajemen. Informasi keuangan yang disampaikan manajemen, oleh para investor digunakan untuk menganalisis kinerja manajemen dan kondisi perusahaan di masa yang akan datang guna mengurangi risiko investasi. Agar publik mau melakukan investasi pada perusahaan dan percaya terhadap rendahnya risiko investasi, maka perusahaan harus menampilkan keunggulan dan eksistensi perusahaan terhadap publik. Salah satu caranya adalah dengan mengungkapkan mengenai tanggung jawab sosial perusahaan (CSR). Semakin besar komposisi saham perusahaan yang dimiliki publik, maka dapat memicu melakukan pengungkapan secara luas termasuk pengungkapan CSR.

\section{Hipotesis}

Berdasarkan latar belakang, masalah pokok dan tinjauan pusataka pada bab sebelumnya, maka hipotesis dalam penelitian ini yaitu:

$\mathrm{H}_{1} \quad$ Ukuran dewan komisaris memiliki pengaruh terhadap pengungkapan CSR dalam laporan tahunan perusahaan di Indonesia

$\mathrm{H}_{2} \quad$ Tipe industri memiliki pengaruh terhadap pengungkapan CSR dalam laporan tahunan perusahaan di Indonesia

$\mathrm{H}_{3} \quad$ Ukuran perusahaan memiliki pengaruh terhadap pengungkapan CSR dalam laporan tahunan perusahaan di Indonesia

$\mathrm{H}_{4} \quad$ Profitabilitas memiliki pengaruh terhadap pengungkapan CSR dalam laporan tahunan di Indonesia

$\mathrm{H}_{5} \quad$ Kepemilikan saham publik memiliki pengaruh terhadap pengungkapan CSR dalam laporan tahunan di Indonesia

\section{Metode Penelitian}

\section{Lokasi dan Waktu Penelitian}

Penelitian di lakukan pada perusahaan Go Public yang terdaftar di BEI utamanya perusahaan manufaktur dengan mengacu kepada data yang terdapat di Pusat Informasi Pasar Modal (PIPM) Makassar, situs resmi BEI (www.idx.co.id). Peneliti memiliki lokasi tersebut karena mudah dijangkau dari tempat tinggal peneliti dan tidak memerlukan biaya yang besar, waktu penelitian diperkirakan ini diperkirakan sekitar 2 bulan.

\section{Populasi dan Sampel}

Populasi pada dasarnya adalah objek yang akan diteliti, adapun yang akan dijadikan populasi dalam penelitian ini adalah data perusahaan manufaktur yang terdaftar di Bursa Efek Indonesia (BEI)dan sahamnya aktif diperdagangkan selama tahun 2011 dan 2012. Populasi yang akan menjadi objek penelitian ini adalah perusahaan manufaktur yang terdaftar di Bursa Efek Indonesia (BEI) serta 
menerbitkan laporan keuangan tahunan (annual report) dan dipublikasikan di Bursa Efek Indonesia (BEI) tahun 2011 - 2012.

Sampel adalah bagian dari populasi yang dianggap dapat mewakili populasi. Adapun kriteria yang menjadi sampel dalampenelitian ini adalah.

1. Perusahaan-perusahaan yang terdaftar di BEI dan sahamnya aktif diperdagangkan selama tahun 2011 dan 2012.

2. Perusahaan tersebut menerbitkan laporan tahunan lengkap untuk periode 2011 dan 2012.

3. Perusahaan tersebut menyediakan informasi yang lengkap mengenai profil dewan komisaris, pelaksanaan CSR, dan laporan komposisi pemegang saham di dalam perusahaan.

\section{Jenis dan Sumber Data \\ Jenis data}

Data yang digunakan dalam penelitian ini adalah berupa data panel. Data panel ini merupakan gabungan antara data time seriesdan cross-sectional. Data time seriesmerupakan data yang dikumpulkan dari waktu ke waktu, pada satu obyek dengan tujuan menggambarkan perkembangan. Data cross-sectionaladalah data yang dikumpulkan pada satu waktu tertentu pada beberapa obyek dengan tujuan untuk menggambarkan keadaan.

\section{Sumber data}

Data yang digunakan dalam penelitian ini adalah data sekunder. Data sekunder diperoleh dari annual report dan laporan keuangan tahunanperusahaan manufaktur yang terdaftar di Bursa Efek Indonesia (BEI) untuk tahun 2011 dan 2012. Data tersebut diperoleh dari kantor BEI Pettarani Makassar.

\section{Teknik Pengumpulan Data}

Data yang digunakan dalam penelitian ini adalah data sekunder, yakni annual report dan laporan tahunan perusahaan tahun 2011 dan 2012. Metode pengambilan data yang digunakan adalahmetode dokumentasi, yaitu penggunaan data yang berasal dari dokumen-dokumen yang sudah ada. Metode pengambilan sampel, yang digunakan dalam penelitian ini adalah metode purposive sampling. Hal ini dikarenakan penelitian inimenggunakan seluruh populasi penelitian yang memenuhi kriteria sebagai sampel penelitian yang sudah ditentukan.

\section{Variabel Penelitian Dan Defenisi Operasional}

Agar penelitian ini dapat dilaksanakan sesuai dengan yang diharapkan, maka perlu dipahami berbagai unsur-unsur yang menjadi dasar dari suatu penelitian ilmiah yang termuat dalam operasional variabel penelitian. Secara rinci operasional variabel penelitian adalah sebagai berikut:

\section{Variabel terikat (dependen)}

Variabel terikat dalam penelitian ini adalah tingkat pengungkapan CSR yang diukur menggunakan Corporate Social Responsibility Index (CSRI). Instrumen pengukuran $C S R I$ yang akan dilakukan dalam penelitian ini mengacuh 
pada instrumen yang dilakukan oleh Angraini (2006), yang mengelompokkan informasi CSR ke dalam tiga kategori, yaitu: aspek kinerja ekonomi, aspek kinerja lingkungan, dan aspek kinerja sosial. Aspek kinerjasosial dibagi dalam empat kategori, antara lain: praktek kinerja, hak manusia, sosial, dan tanggung jawab terhadap produk. Menurut Angraini (2006), kategori informasi Sustainability Reporting menjadi dasar yang digunakan untuk mengukur pengungkapan Corporate Social Responsibility index (CSRI) sebagai berikut.

KE : Kinerja Ekonomi

KL : Kinerja Lingkungan

PK : Praktik Kerja

HM : Hak Asasi Manusia

Sos : Sosial

TP : Tanggung jawab Terhadap Produk

Pengukuran CSRI mengacuh pada penelitian Haniffa et aL (2005) pada penelitian Sayekti dan Wondabio (2007), yaitu dengan menggunakan contens analysis dalam mengukur variety dari CSRI. Pendekatan ini pada dasarnya menggunakan pendekatan dikotomi, yaitu setiap kategori informasi pengungkapan CSR dalam instrumen penelitian diberi skor 1 jika informasi yang diungkapkan ada dalam laporan tahunan, dan nilai 0 jika kategori informasi tidak diungkapkan di dalam laporan tahunan. Selanjutnya, skor dari setiap kategori informasi Sustainability Reporting dijumlahkan untuk memperoleh keseluruhan skor untuk setiap perusahaan.

\section{Variabel bebas (independen) \\ Ukuran dewan komisaris}

Ukuran dewan komisaris (UDK) yang dimaksud disini adalah banyak jumlah anggota dewan komisaris dalam suatu perusahaan. Ukuran dewan komisaris dalam penelitian ini yaitu dilihat dari banyaknya jumlah anggota dewan komisaris perusahaan.

\section{Tipe Industri}

Tipe industri diukur dengan menggunakan variabel dummy, yaitu pemberian skor 1 untuk perusahaan yang termasuk dalam industri high-profile, dan skor 0 untuk perusahaan yang termasuk dalam industri low-profile. Kriteria untuk menentukan perusahaan termasuk high-profile dan low-profile digunakan pengelompokan menurut Preston (1977) pada penelitian yang pernah dilakukan oleh Angraini (2006). Perusahaan-perusahaan yang termasuk dalam industri migas, kehutanan, pertanian, pertambangan, perikanan, otomotif, barang konsumsi, makanan dan minuman, kertas, farmasi, dan konstruksi sebagai industri high-profile.

\section{Ukuran Perusahaan}

Ukuran perusahaan diukur dari total aset yang dimiliki perusahaan yang diperoleh dari laporan tahunan perusahaan untuk tahun 2011 dan 2012. Size perusahaan yang diukur dengan total aset akan ditransformasikan dalam logaritma 
untuk menyatakan dengan variabel lain karena total aset perusahaan nilainya relatif besar dibandingkan variabel-variabel lain dalam penelitian ini.

\section{Profitabilitas}

Profitabilitas diartikan sebagai kemampuan perusahaan untuk menghasilkan laba atau profit dalam upaya meningkatkan nilai pemegang saham. Profitabilitas perusahaan diukur dengan Return On Asset (Belkaoui dan Karpik, 1989 pada penelitian yang pernah dilakukan oleh Angraini, 2006). Return On Asset (ROA) merupakan ukuran efektifitas perusahaan di dalam menghasilkan keuntungan dengan memanfaatkan aktiva yang dimilikinya.

\section{Kepemilikan Saham Publik}

Kepemilikan saham publik adalah juml;ah lembar saham yang diliki oleh masyarakat terhadap saham perusahaan di Indonesia. Kepemilikan saham publik tersebut dapat dilihat dalam laporan tahunan perusahaan. Besarnya saham publik/masyarakat diukur melalui rasio dari jumlah kepemilikan lembar saham yang dimiliki publik terhadap total saham perusahaan di Indonesia. Metode pengukuran di atas berdasarkan pengukuran yang telah dilakukan oleh Puspitasari (2009).

\section{Metode Analisis}

\section{Analisis Data}

Analisis data yang digunakan dalam penelitian ini adalah sebagai berikut :

\section{Pengukuran CSRI}

CSRIy $=\Sigma$

Keterangan.

CSRIy: Corporate Social Responsibility Index perusahaany,

$\Sigma$ Xky: Dummy variable: $1=$ jika kategori Sustainability Reporting $\mathrm{k}$ diungkapkan; 0 = jika kategori Sustainability Reporting tidak diungkapkan.

\section{Pengukuran UDK.}

UDK $=\Sigma$ Dewan Komisaris Perusahaan

\section{Pengukuran Ukuran perusahaan.}

$S I Z E=\log$ (nilai buku total aset)

\section{Pengukuran Profitabilitas (ROA)}

$\mathrm{ROA}=$

\section{Pengukuran Kepemilihan Saham Publik}

Rasio $=\longrightarrow \quad 100 \%$

Untuk menguji hipotesis, penelitian ini mengunkan pengujian statistik regresi lineras berganda dengan persamaan analisis sebagai berikut :

$C S R I=\beta 0+\beta 1$ UDKit $+\beta 2$ TYPEit $+\beta 3$ LSIZEit $+\beta 4$ ROAit $+\beta 5$ PSit $+\varepsilon i t$

Keterangan : 
CSRI : Indeks pengungkapan CSR

Type : Tipe Industri, high-profile $=1$, low-profile $=0$

LSIZE : Ukuran perusahaan, log total aset

ROA : Profitabilitas, proksi ROA

PS : Persentase kepemilikan publik

B1 .... B6: Koefisien variabel bebas

cit : Error term

\section{Hasil Penelitian}

\section{Pengujian Secara Parsial}

\section{Ukuran Dewan Komisaris (X1)}

Berdasarkan tabel hasil uji t dapat diketahui bahwa nilai t untuk variabel $\mathrm{X} 1$ adalah positif. Hal ini berarti bahwa semakin banyak jumlah dewan komisaris dalam suatu perusahaan maka semakin besar pengungkapan CSR perusahaan tersebut, begitupun sebaliknya semakin sedikit jumlah dewan komisaris dalam suatu perusahaan maka semakin kecil pula pengungkapan CSR perusahaan tersebut. Nilaisig $0,011<0,05$, berarti variabel X1berpengaruh signifikan terhadap variabel Y.Dari hasil tersebut, hipotesis H1 (Ukuran Dewan Komisaris berpengaruh positif terhadap pengungkapan $C S R$ ) diterima.

Adanya hubungan antara ukuran dewan komisaris dengan pengungkapan CSR mengandung arti bahwa semakin banyak jumlah dewan komisaris dalam suatu perusahaan maka akan memperluas tingkat pengungkapan CSR suatu perusahaan. Keadaan ini terjadi karena apabila dalam suatu perusahaan memiliki dewan komisaris yang banyak, maka akan semakin mudah untuk mengendalikan Chief Executive Officer (CEO) dan monitoring yang dilakukan semakin efektif sehingga semakin mudah untuk menekan $C E O$ untuk mengungkapkan $C S R$.

\section{2. $\quad$ Tipe Industri (X2)}

Berdasarkan tabel hasil uji t dapat diketahui bahwa nilai t untuk variabel $\mathrm{X} 2$ adalah positif. Hal ini menunjukkan semakin high profile suatu perusahaan maka akan semakin besar pula pengungkapan CSR suatu perusahaan itu begitupun sebaliknya semakin low profile suatu perusahaan maka akan kecil pula pengungkapan CSR perusahaan tersebut. Nilai sig 0.890>0,05, berarti variabel X2 tidak berpengaruhsignifikan terhadap variabel Y akan tetapi hipotesis H2 (Tipe Industri berpengaruh positif terhadap luas pengungkapan CSR) tetap diterima.

Adanya hubungan yang signifikan antara tipe industri dan pengungkapan CSR mengandung arti bahwa tipe industri high-profile merupakan perusahaan yang mempunyai tingkat sensivitas yang tinggi terhadap lingkungan, tingkat risiko politik yang tinggi atau tingkat kompetisi yang ketat. Keadaan tersebut membuat perusahaan menjadi lebih mendapatkan sorotan oleh masyarakat luas mengenai aktivitas usaha yang digerakkannya sehingga memaksa perusahaan untuk mengungkapkan $C S R$.

\section{Ukuran Perusahaan (X3)}

Dari hasil uji t dapat dijelaskan bahwa nilai t untuk variabel $\mathrm{X} 3$ adalah negatif. Hal ini menunjukkan semakin besar ukuran perusahaan semakin kecil 
pula pengungkapan $C S R$ perusahaan itu begitu pula sebaliknya semakin kecil suatu perusahaan maka semakin besar pula pengungkapan CSR perusahaan tersebut. Nilai sig 0,700>0,05, berarti variabel X3 tidak berpengaruh signifikan dan hipotesis H3 (Ukuran Perusahaan berpengaruh positif terhadap luas pengungkapan $C S R$ ) tidak berpengaruh signifikan terhadap variabel $\mathrm{Y}$ dan hipotesis ditolak.

\section{Profitabilitas}

Hasil uji t menunjukkan bahwa nilai t untuk variabel $\mathrm{X} 4$ adalah positif. Hal tersebut menunjukkan bahwa semakin besar profitabilitas suatu perusahaan maka akan semakin besar pula pengungkapan CSR perusahaan tersebut, begitu pula sebaliknya semakin kecil profitabilitas suatu perusahaan maka akan semakin kecil pula pengungkapan $C S R$ perusahaan itu. Nilai sig0,246>0,05 berarti variabel X4 (Tingkat Profitabilitas perusahaan berpengaruh negatif terhadap luas pengungkapan $C S R$ )tidak berpengaruh signifikan terhadap variabel $\mathrm{Y}$ dan hipotesisditerima.

\section{Kepemilikan Saham Publik}

Berdasarkan hasil uji t dapat dijelaskan bahwa nilai t untuk variabel X5 adalah positif. Hal ini menunjukkan bahwa semakin banyak saham yang dimiliki oleh pihak publik maka akan semakin besar pula pengungkapan CSR perusahaan begitu pula sebaliknya semakin kecil saham yang dimiliki oleh publik maka semakin kecil pula pengungkapan $C S R$ perusahaan tersebut. Nilai sig $0,005<0,05$ berarti variabel X6 (Besarnya Kepemilikan Saham Publik berpengaruh positif terhadap pengungkapan $C S R$ ) berpengaruh signifikan terhadap variabel $\mathrm{Y}$ dari hasil tersebut hipotesis diterima.

\section{Pengujian Koefisien Determinasi (R2)}

Koefisien determinasi (R) berguna untuk mengukur seberapa besar peranan variabel independen yaitu ukuran dewan komisaris, tipe industri, ukuran perusahaan, profitabilitas, dan kepemilikan saham publiksecara bersama-sama menjelaskan perubahan yang terjadi pada variabel dependen yaitu $C S R$.

Berikut ini hasil uji koefisien determinasi (R2):

\section{Hasil Uji Koefisien Determinasi}

\begin{tabular}{|c|c|c|c|c|}
\hline Model & $\mathrm{R}$ & $\mathrm{R}$ Square & Adjusted R Square & Std. Error of the Estimate \\
\hline 1 & $.431^{\mathrm{a}}$ & .186 & .134 & .97737902 \\
\hline
\end{tabular}

Sumber: hasil pengolahan data SPSS 16,00

Tabel di atas menunjukkan bahwa nilai R Square (R) adalah sebesar 0,186 hal ini berarti bahwa pengaruh ukuran dewan komisaris, tipe industri, ukuran perusahaan, profitabilitas, dan kepemilikan saham publik terhadap CSR adalah 18,6 persen, sedangkan sisanya 81,4 persen dipengaruhi oleh faktor-faktor lain yang tidak termasuk dalam variabel penelitian ini. 


\section{Kesimpulan dan Saran \\ Kesimpulan}

Berdasarkan hasil analisis penelitian yang telah dilakukan, mencerminkan bahwa pengungkapan CSR akan meningkat secara signifikan jika terjadi peningkatan yang signifikan pula pada ukuran dewan komisaris, tipe industri, profitabilitas dan kepemilikan saham publik, sedangkan ukuran perusahaan tidak berpengaruh signifikan terhadap laporan pengungkapan CSR.

\section{Saran}

Beberapa saran yang dapat peneliti berikan untuk perbaikan atau peningkatan kinerja lebih lanjut dimasa yang akan datang setelah meneliti pengunkapan CSR adalah sebagai berikut: Bagi entitas bisnis, sebaiknya memperhatikan laporan pengungkapan CSR entitas terkait karena laporan pengungkapan CSR dapat mempengaruhi reputasi perusahaan dan mengundang investor untuk menanamkan modalnya di perusahaan tersebut. Dan bagi pemerintah, sebaiknya memperketat pengawasan terhadap perusahaan (Perseroan Terbatas) terkait laporan pengungkapan CSR sebagaimana yang dijelaskan dalam Undang-Undang PT Pasal 74 tentang Tanggung Jawab Sosial dan Lingkungan hidup.

\section{DAFTAR PUSTAKA}

Angraini, R., Reni. 2006. Pengungkapan Informasi Sosial dan Faktor-Faktor yang Mempengaruhi Pengungkapan Informasi Sosial dalam Laporan Keuangan Tahunan (Studi Empiris pada Perusahan-Perusahaan yang terdaftar Bursa Efek Jakarta). Skripsi (Online), (blog.umy.ac.id. diakses 14 Februari 2013).

Arian, Agung. 2005. Struktur Pengendalian Intern. Doc. (Online), (http://elib.unikom.ac.id- . diakses 10 Maret 2013 ).

Agusti, Restu. 2013. Pengaruh Economic Performance Dan Political Visibility Terhadap Pengungkapan Corporate Social Responsibility, (Online), (ejournal.unri.ac.id/index.php/ diakses 15 Maret 2013).

Amran, Azlan dan Devi, Susela, S. 2008. "The Impact Of Goverment And Foreign Affiliate Influence On Corporate Sosial Reporting (The Case Of Malaysia)”. Skripsi (Online), (http://www.emeraldinsight.com. diakses 10 Maret 2013).

Elisabet, Inge Mawarani. 2010. Pengaruh Pengungkapan Corporate Social Responsibility (CSR) Terhadap Profitabilitas Perusahaan Pertambangan Di Bursa Efek Indonesia. Desertasi diterbitkan. Jatim: UPN Vetran Jatim.

Ghozali, Imam. 2009. Aplikasi Analisis MultivariateDengan Program SPSS. Semarang. Badan penerbit UNDIP.

Ikatan Akuntan Indonesia. 2009. Standar Akuntansi Keuangan Per 1 Januari 2009. Jakarta: Salemba Empat

Indrawati, Novita. 2009. Pengungkapan Corporate Social Responsibility (CSR) Dalam Annual Report Serta Pengaruh Political Visibility Dan Ekonomic Performance. (Online) Vol 1, No. 1, (ejournal.unri.ac.id/index.php, diakses 15 Maret 2013). 
Kusumadilaga, Rimba. 2010. Pengaruh Corporate Sosial Responsibility Terhadap Nilai Perusahaan Dengan Profitabilitas Sebagai Variabel Moderating (Studi Empiris Pada Perusahaan Manufaktur Yang Terdaftar Di Bursa Efek Indonesia). Skripsi. Semarang: Universitas Diponegoro.

Mahatma, Angling. 2010. Pengaruh Karakteristik Perusahaan Dan Regulasi Pemerintah Terhadap Pengungkapan Corporate Social Responsibility (CSR) Pada Laporan Tahunan Di Indonesia. Skripsi. Jurusan Akuntansi Fakultas Ekonomi Universitas Diponegoro.

Machmud, Novita dan Djakman, D. Chaerul. 2008. Pengaruh Struktur Kepemilikan Terhadap Luas Pengungkapan Tanggung Jawab Sosial (CSR Disclousure) Pada Laporan Tahunan Perusahaan: Studi Empiris pada Perusahaan Publik yang Terdaftar DI Bursa Efek Indonesia Tahun 2006.

Moon, Jeremy. 2004. International Centre for Corporate Social Responsibility. Dalam Matten Dirk (Ed.), (hlm. 6). Inggris: Nottingham University Bussines School.

Mulyady dan Puradireja, Kanaka. 1998. Auditing (ed.5) Jakarta; Salemba Empat.

Muchlisin. 2009. Pelaksanaan CSR (Corporate Social Responsibility) Sebagai

Tanggung Jawab Perusahaan Berdasarkan Undang-Undang Nomor 40 Tahun 2007 Tentang Perseroan Terbatas (Studi di PT. Air Mancur.).

Nabella. 2012. Tanggung Jawab Sosial Perusahaan, (Online), (nabella2326.blogspot.com, diakses 10 Februari 2013).

Nurkin, Ahmad. 2009. Corporate Governance Dan Profitabilitas ; Pengaruhnya Terhadap Pengungkapan Tanggung Jawab Sosial Perusahaan (Studi Empiris Pada Perusahaan Yang Terdaftar Di Bursa Efek Indonesia), (Online), (eprints.undip.ac.id, diakses 15 Maret 2013).

Nur, Marzully dan Priantinah, Denies. 2012. Analisis Faktor-Faktor Yang Mempengaruhi Pengungkapan Corporate Social Responsibility Di Indonesia (Studi Empiris Pada Perusahaan Berkategori High Profile Yang Listing Di Bursa Efek Indonesia), (Online), (journal.uny.ac.id/indeks/php, diakses 15 Maret 2013).

Indrawan, Danu, Candra. 2011. Pengaruh Corporate Social Responsibility Terhadap Kinerja Perusahaan. Skripsi tidak diterbitkan, (Online), (eprints.undip.ac.id, diakses 15 Juni 2013).

Petkoski, Djordjija, dan Twose Nigel, 2003. Public Policy for Corporate Social Responsibility,(Online),(http://info.worldbank.org/etools/docs/library/5743 4/publicpolicy_econference.pdf, diakses 15 Maret 2013).

Putri, M,. Suhandari. 2007. Schema CSR. Kompas, hal 1. Jakarta. Sinar Grafika.

Purwamitha, M, Armitha. 2011. Hubungan Corporate Disclousure Dan Earnings Manajement: Studi Empiris Berdasarkan Political Cost Hypothesys. Skripsi tidak diterbitkan (Online), Semarang:UNDIP (eprints.undip.ac.id, diakses 20 Maret 2013).

Putra, Eka, Nanda. 2011. Pengaruh Karakteristik Perusahaan Terhadap Pengungkapan Corporate Social Responsibility (CSR). Skripsi tidak diterbitkan (Online) Semarang:UNDIP (eprints.undip.ac.id, diakses 20 Maret 2013). 
Prianto, Agus. 2012. Persepsi Tentang Implementasi CSR Dan Pengaruhnya Terhadap Dukungan Kelangsungan Kegiatan Usaha.

Puspitasari, Daning Apriani. 2009. Faktor-Faktor Yang Mempengaruhi Pengungkapan Corporate Social Responsibility (CSR) Pada Laporan Tahunan DI Indonesia. (Online), (eprints.undip.ac.id, diakses 10 Maret 2013).

R, Nugraha, Hanggara Ariwenda. 2011. Pengaruh Pelaksanaan Program Corporate Social Responsibility Terhadap Profitabilitas Pada Perusahaan Telekomunikasi Yang Terdaftar Pada Bursa Efek Indonesia.

Rosmasita, Hardina. 2007. Faktor-Faktor yang Mempengaruhi Pengungkapan Sosial (Social Disclousure) Dalam Laporan Tahunan Perusahaan Manufaktur Di Bursa Efek Jakarta.

Rustiarini, Ni, Wayan. 2011. Pengaruh Struktur Kepemilikan Saham Pada Pengungkapan Corporate Social Responsibility, (Online), (eprints.undip.ac.id, diakses 15 Maret 2013).

Sally, Ria.N., Anugerah, R. \& Dwiningsih, R. 2010. Pengaruh Struktur Kepemilikan, Kualitas Audit Dan UkuranPerusahaan Terhadap Transparansi Informasi(Studi Empiris pada 100 Perusahaan Publik Terbesar di Indonesia), (Online), Vol 2 No. 3 (ejournal.unri.ac.id diakses 15 Maret 2013).

Sayekti, Yosefa dan W., Sensi, Ludovicus. 2007. Pengaruh CSR DisclousureTerhadap Earning Respon Coefficient (Suatu Studi Empiris Pada Perusahaan Yang Terdaftar DI Bursa Efek), (Online), (staff.blog.ui.ac.id, diakses 15 Maret 2013).

Santoso, Singgih. 2012. Panduan Lengkap SPSS Versi 21. Jakarta: Elex Media Komputindo. Siiekha. 2012. Tanggung Jawab Sosial Perusahaan atau CSR.

Undang-Undang Republik Indonesia Nomor 40 Tahun 2007 Tentang Perseroan Terbatas Pasal 74 dan Pasal 66 ayat (2) bagian C. 